\title{
STUDI FENOMENOLOGI RESPON BERDUKA AKIBAT PERCERAIAN ORANG TUA PADA REMAJA DI SMPN 5 JAHAB TENGGARONG KUTAI KARTANEGARA
}

\author{
Study of Phenomenology of Grieving Response As A Result of Parental Divorce to Adolescents of \\ Junior High School 5 Jahab, Tenggarong, Kutai Kartanegara
}

\author{
Rusdi $^{1}$, Edy Mulyono ${ }^{1}$, Sheela Christina ${ }^{1}$, Linda Dwi Novial Fitri ${ }^{2}$ \\ 1 STIKes Wiyata Husada Samarinda \\ ${ }^{2}$ RSJD Atma Husada Mahakam Samarinda \\ Email : rusdi.psikwhs17@gmail.com
}

\begin{abstract}
The process of divorce begins with a period of marriage conflict with varying duration and intensity. It might be followed by separation, legal divorce, and the re-establishment of different living arrangements. Divorce might impact deeply and adversely for the whole family. One of the individuals affected by the divorce is a child in the family. In this case, the child is an adolescent. The adolescent who experiences parental divorce may feel the loss and feelings of grief are as deeply grieving as they lose their parents for dying. The purpose of this study was to obtain a description of grieving response due to parental divorce towards adolescents. Methods: This research applied qualitative research with Phenomenology approach. Informants in this study were 4 adolescents. In the research, Taking an informant using technique of Purposive sampling. The results of data analysis of themes based on memos and coding process. Results: Interviews with the informants resulted in three themes 1) Adolescents knowledge about parental divorce, 2) Adolescents attitude affected by their divorced parents, 3) Adolescents response after their parents got divorced. Conclusion: Forms of response experienced by adolescents due to parental divorce in the form of effective responses.

Keywords : Divorce, Parental divorce, Adolescent, Grieving Response
\end{abstract}

\begin{abstract}
Abstrak
Proses perceraian dimulai dengan suatu periode konflik perkawinan dengan lama dan intensitas beragam, diikuti oleh perpisahan, perceraian sebenarnya secara hukum, dan pembentukan kembali pengaturan kehidupan yang berbeda. Perceraian akan berdampak mendalam bagi seluruh anggota keluarga. Salah satu individu yang terkena dampak perceraian yaitu anak dalam keluarga. anak remaja yang mengalami perceraian orang tua merasakan kehilangan dan perasaan berduka yang sangat mendalam sama berdukanya ketika kehilangan orang tua karena meninggal. Tujuan penelitian ini adalah untuk memperoleh gambaran tentang Respon berduka akibat perceraian orang tua pada remaja. Metode : Penelitian ini menggunakan desain Kualitatif dengan pendekatan Fenomenologi. Informan dalam penelitian ini 4 orang remaja. Pengambilan informan dalam penelitian ini menggunakan teknik Purposive sampling. Hasil analisa data berupa tema yang disusun berdasarkan memo dan proses coding. Hasil : hasil wawancara dengan informan menghasilkan tiga tema 1) Pengetahuan remaja tentang perceraian orangtua, 2) Sikap remaja yang orangtua bercerai, 3) Respon remaja setelah orangtua bercerai. Kesimpulan : bentuk respon yang dialami remaja akibat perceraian orangtua berupa respon afektif.
\end{abstract}

Kata Kunci : Perceraian, Orangtua, Remaja, Respon Berduka 


\section{PENDAHULUAN}

Proses perceraian dimulai dengan suatu periode konflik perkawinan dengan lama dan intensitas beragam, diikuti oleh perpisahan, perceraian sebenarnya secara hukum, dan pembentukan kembali pengaturan kehidupan yang berbeda (Wong,2009). Perceraian merupakan jatuhnya sebuah keluarga, yang seringkali memberikan pengalaman sakit yang mungkin berakibat jangka panjang seperti, kehilangan pendapatan dan berkurangnya ikatan orang tua. Perceraian orang tua berhubungan dengan harga diri rendah dan kesulitan besar dalam interaksi perilaku dengan contoh klinis remaja. Banyak studi menunjukan bahwa konflik pada orang tua dan selama perpisahan dan setelah perpisahan bisa membuat dampak negative pada anak-anak dengan psikologi yang baik. (Brownlee, 2007).

Respon Berduka adalah respon emosi yang diekspresikan terhadap kehilangan yang dimanifestasikan adanya perasaan sedih, gelisah, cemas, sesak nafas, susah tidur, dan lain-lain. Berduka merupakan respon normal pada semua kejadian kehilangan. Respon Berduka merupakan suatu bentuk dari perubahan dari suatu yang semula ada menjadi tidak ada atau suatu kondisi dimana tidak terjadinya sebuah situasi yang diharapakan. (Keliat, Novi, \& Farida, 2007). Adanya kondisi seperti ini dapat membawa remaja pada keadaan emosi yang tidak stabil karena belum tercapainya kematangan kepribadian dan pemahaman nilai sosial remaja sebagai manusia yang sedang berkembang menuju tahap dewasa yang mengalami perubahan dan pertumbuhan yang pesat. Perkembangan pada masa remaja pada dasarnya meliputi aspek fisiologi, aspek psikologis dan aspek social.

Perkembangan aspek fisiologi ditandai dengan berfungsinya hormon dan perubahan suara. Perkembangan psikologis meliputi keadaan emosi, kognisi dan pemahaman tentang diri pribadi sosial meliputi pemahaman nilai social dan melakukan interaksi sosial dengan teman sebaya (Santrock, 2012). Respon berduka adalah respon emosi yang diekspresikan terhadap kehilangan yang dimanifestasikan adanya perasaan sedih, gelisah, cemas, sesak nafas, susah tidur, dan lain-lain. Berduka merupakan respon normal pada semua kejadian kehilangan. Respon Berduka merupakan suatu bentuk dari perubahan dari suatu yang semula ada menjadi tidak ada atau suatu kondisi dimana tidak terjadinya sebuah situasi yang diharapakan. (Keliat, Novi, \& Farida, 2007).

Beberapa jenis respon berduka, yaitu respon berduka normal, respon berduka antisipatif, respon berduka yang rumit, dan respon berduka tertutup. Tahap-tahap respon berduka meliputi tahap pengingkaran, tahap marah, tahap tawar-menawar, tahap depresi dan tahap penerimaan (Suseno, 2005).

Respon berduka yang dirasakan oleh remaja karena orangtuanya bercerai, yaitu antara lain: (1) adanya rasa penolakan dari keluarga Anak remaja dari korban keluarga bercerai merasakan penolakan dari keluarga sebab sikap orangtua berubah. Disini psikologi anak remaja tergganggu akibat perceraian orangtua nya ; (2) Perihal rasa tidak aman ini menyangkut aspek financial dan masa depan, sebab seorang anak ini berpikiran bahwa masa depannya akan suram. . Biasanya anak tersebut akan cenderung introvert (menutup diri) terhadap sosialnya sebab ia tidak merasa aman saat berada di lingkungan sosial dan ia menganggap lingkungannya adalahhal-hal yang negative yang bias mengancam kehidupannya ; (3) Marah Dengan adanya perceraian seorang anak seringkali emosinya tidak terkontrol dengan baik sehingga mereka sering kali marah yang tidak karuan, banyak teman dekat yang menjadi sasaran amarahnya. Amarah dan agresif merupakan reaksi yang lazim dalam perceraian, hal itu terjadi bila orang tuanya marah di depan anaknya ; (4) Sedih, seorang anak akan merasa nyaman dengan orang tua nya yang harmonis namun sebaliknya ia akan bersedih jika orang tua mereka berpisah atau bercerai dan saat sudah remaja merasa kehilangan (Suseno, A. (2005).

Perceraian merupakan cerai hidup atau perpisahan hidup antara pasangan suami istri sebagai akibat dari kegagalan mereka menjalankan kehidupan rumah tangga dalam masing-masing peran. Dalam hal ini perceraian dilihat sebagai akhir akhir dari suatu ketidakstabilan perkawinan dimana suami istri kemudian hidup terpisah. Perceraian 
merupakan terputusnya keluarga karena salah satu atau kedua pasangan memutuskan untuk saling meninggalkan sehingga mereka berhenti melakukan kewajibannya sebagai suami istri. Perceraian terjadi apabila kedua belah pihak suami maupun istri sama-sama merasakan ketidakcocokan dalam menjalani rumah tangga (Agustiani, H., 2006).

Undang-Undang Nomor 1 tahun 1974 tentang Perkawinan tidak memberikan definisi mengenai perceraian secara khusus. Pasal 39 Ayat 2 Undangundang perkawinan serta penjelasannya secara jelas menyatakan bahwa perceraian dapat dilakukan apabila sesuai dengan alasan-alasan yang telah ditentukan. Definisi perceraian di Pengadilan Agama itu, dilihat dari putusnya perkawinan. Putusnya perkawinan dalam Undang-undang Perkawinan, yaitu : (1) karena kematian ; (2) karena perceraian; dan (3) karena putusnya pengadilan. Tujuan penelitian ini adalah untuk memperoleh gambaran tentang Respon berduka akibat perceraian orang tua pada remaja.

\section{BAHAN DAN METODE}

Rancangan pendekatan yang digunakan dalam penelitian ini adalah pendekatan Fenomenologi. Penelitian fenomenologi berorientasi untuk memahami, menggali, dan menafsirkan arti dan peristiwa-peristiwa, dan hubungan dengan orang-orang yang biasa dalam posisi tertentu. Penelitian ini dilaksanakan pada bulan Juni 2017 di SMPN 5 Jahab Tenggarong Kutai Kartanegara. Subjek penelitian atau informan adalah orang yang diminta untuk memberikan keterangan tentang suatu fakta atau pendapat. Subjek dalam penelitian ini adalah Remaja SMPN 5 Jahab Tenggarong Kutai Kartanegara. Unit analisis dalam penelitian ini adalah Remaja SMPN 5 Jahab Tenggarong Kutai Kartanegara. Penentuan informan dalam penelitian ini menggunakan Purposive sampling untuk memperluas data penelitian dengan kriteria informan : (1) remaja yang berada di SMPN 5 Jahab Tenggarong Kutai Kartanegara ; ( 2) remaja yang berstatus pelajar ; (3) remaja tengah dengan usia 13 15 tahun ; dan (4) remaja yang bersedia menjadi informan.

Teknik pengumpulan data yaitu menggunakan observasi tidak berstruktur untuk memahami dan menafsirkan berduka pada remaja, pertanyaan langsung oleh peneliti kepada partisipan, dan jawaban partisipan direkam atau dicatat/ didokumentasikan. Analisis data dengan menggunakan dengan menentukan koding, kemudian membuat tema atau kategori dan dilanjutnya dengan membuat memo dalam menentukan kategori inti.

\section{HASIL DAN PEMBAHASAN}

Peneliti menggambarkan keseluruhan tema yang terbentuk berdasarkan jawaban informan terhadap pertanyaan-pertanyaan yang mengacu pada tujuan khusus penelitian. Tiga tujuan khusus terjawab dalam empat tema analisis penelitian, sehingga narasi penjelasan sesuai tujuan khusus yang diuraikan dalam urutan penomoran mulai tema yang pertama sampai yang ketiga.

Tema 1 : Pengetahuan remaja tentang perceraian orangtua : pengetahuan informan tentang perceraian meliputi tentang pendapat tentang perceraian. Hampir semua informan mengatakan bahwa perceraian merupakan sebuah perpisahan antara ayah dan ibu. Pengetahuan remaja tentang perceraian diungkapkan sebagai pemahaman tentang perceraian secara umum.

Sesuai dengan hasil wawancara dilakukan kepada 4 informan pemahaman tentang perceraian, diketahui informan 1 mengatakan perceraian merupakan perpisahan yang menyakitkan buat anak-anaknya; Informan 2, 3, dan 4 mengatakan perceraian merupakan perpisahan antara kedua orangtua. Peneliti akan menampilkan hasil wawancara dari informan seperti dibawah ini : kata kunci terkait Perpisahan :

"perceraian itu perpisahan orangtua yang menyakitkan buat anaknya" (I1)

"Perceraian itu tentang perpisahan kedua orangtua gitu" (I2)

"Perpisahan antara mamak sama ayah" (I3)

"Perceraian itu, ya perpisahan ya, ibu saya dan ayah saya ! udah gitu gak tau lagi" (I4).

Tema 2 : sikap remaja yang orangtua bercerai : Penelitian ini juga berusaha untuk memperoleh pemahaman yang mendalam tentang karakter dari 
Sub Tema

Perpisahan

Sub Tema

\begin{tabular}{|l|}
\hline Bunuh Diri \\
\hline Kehilangan \\
\end{tabular}

Sub Tema

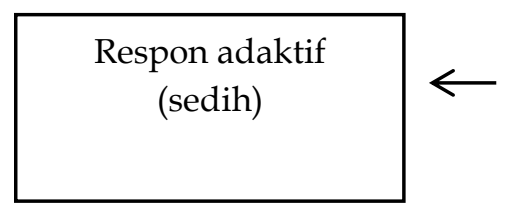

Tema

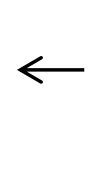

Tujuan

\section{Menjelaskan \\ pengetahuan remaja \\ tentang perceraian}

Gambar 1. Tema 1

Tema

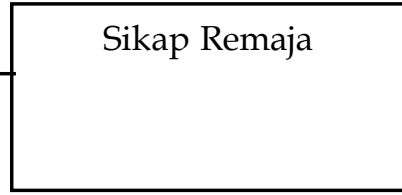

Gambar 2. Tema 2

Tujuan

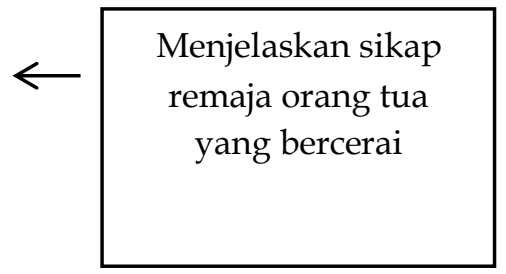

Tema

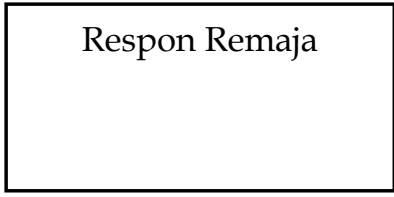

Gambar 3. Tema 3
Tujuan

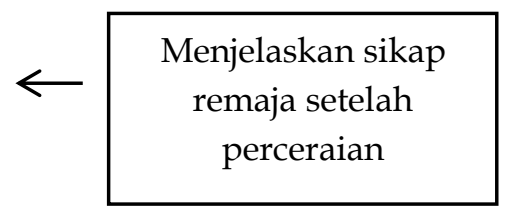

remaja. Jawaban informan kemudian dikelompokan menjadi jawaban-jawaban yang terkait sikap, norma subjektif dan persepsi kontrol. Sikap remaja dapat menjelaskan karakteristik selama ini.

Perasaan yang disampaikan oleh beberapa informan terkait dengan hal negatif yang mengancam kehidupan dapat terlihat seperti pernyataan informan dibawah ini : Kata kunci bunuh diri :

"hmm... pengen bunuh diri, capek! baru-baru juga lagi, mama gak ada kabar nya.... (I1)

Kata kunci terkait kehilangan :

"Pas saya tahu pas masuk TK, soalnya awalnya yang saya orangtua itu nenek baru 2 kali ketemu mamak, kalo bapak sering. (I2) Saya kesel, misalnya kalau ada acara nikahan keluarga pasti teman saya itu ada ayahnya ada ibunya, kalau saya cuma sama mamak aja pergi undangan jadi pikirannya ndak enak, kalok ada teman saya yang nanya ayahmu mana, saya ndak bisa jawab, karena dari sebelum masuk TK kan ikut mamak, jadi ya gak tau jawabnya gitu aja.(I3)

"agak gimana ya, pengen punya ayah juga kayak yang lain... iri juga. (I4).

Tema 3. Respon remaja setelah orangtua bercerai Penelitian ini juga untuk mengetahui respon berduka remaja setelah perceraian orangtua. Dari hasil analisis data, diketahui umumnya respon berduka dialami oleh remaja.

Hal ini menimbulkan respon afektif sedih karena orangtua bercerai. Adapun pernyataan dari informan yang menunjukan respon afektif sedih yaitu :

"Paling sedih kak kalok liat anak sama orangtua lagi ngumpul,kami gak ada"(I1)

"sejak umur dua bulan orangtua saya sudah bercerai, dan saya tidak pernah bertemu dengan orangtua saya. Kalok bapak paling setahun sekali, kalok mamak jarang" (I2). "jadi sedih kan nggak ada nasihat dari seorang ayah" (I3). 
"Sedih aja soalnya kan yang lain masih ada ayahnya.. dan gak pernah sama ayah dari kecil.. perasaan saya susah lah kak, ga tau lagi sudah...(I4).

Hasil penelitian yang dilakukan peneliti terhadap remaja yang bersedia menjadi informan diperoleh hasil bahwa semua informan dapat menjelaskan pengertian perceraian. Berkaitan dengan pemahaman dan pengetahuan tersebut sesuai dengan pendapat Notoatmojo (2010) yang menyatakan bahwa pengetahuan adalah "Tahu" dan ini terjadi setelah orang mengadakan penginderaan terhadap suatu objek tertentu. Penginderaan terhadap suatu objek terjadi melalui panca indera manusia, pendengaran, penglihatan, penciuman, rasa dan raba dengan sendiri. Perceraian sejauh ini merupakan cerai hidup atau perpisahan hidup antara pasangan suami istri sebagai akibat dari kegagalan mereka menjalankan kehidupan rumah tangga dalam masing-masing peran. Selanjutnya dikemukakan oleh Dariyo (2007), perceraian merupakan titik puncak dari pengumpulan berbagai permasalahan yang menumpuk beberapa waktu sebelumnya dan jalan terakhir yang harus ditempuh ketika hubungan perkawinan itu sudah tidak dapat dipertahankan lagi.

Secara garis besar keseluruhan subjek remaja pada penelitian ini mengalami dampak dari perceraian orangtuanya, yaitu dampak pada kondisi psikologis dan perilaku para subjek remaja pada penelitian ini dan akhirnya hal tersebut mempengaruhi perasaan dari keempat subjek remaja. Kemudian subjek remaja pada penelitian ini berusaha mengatasi masalahnya dengan berbagai hal seperti kegiatan positif agar mereka lupa sejenak dengan permasalahan orang tua mereka. Pengetahuan tentang perceraian merupakan hal yang perlu remaja ketahui. Kemampuannya dalam menjelaskan pengertian perceraian sangat berpengaruh dengan keadaan psikologis mereka. Berdasarkan hasil penelitian ditemukan fakta dari keempat informan menjawab pengertian perceraian menuurut pengertian sendiri meskipun keempat informan tidak bisa menjelaskan lengkap tentang perceraian, sehingga bisa ditarik kesimpulan bahwa jawaban keempat informan sudah dianggap mewakili dari pengertian dan pengetahuan tentang perceraian.
Asriandari E, (2015) menyatakan bahwa sikap remaja yang orangtua bercerai yang menjadi korban adalah anak. Meskipun, orangtua berpikir bahwa perceraian adalah jalan terbaik bagi keduanya namun tidak bagi anak. Terutama dalam tumbuh kembang dan masa depan mereka. Secara tidak langsung, mereka akan merasa kehilangan perhatian sejak orangtua mereka berpisah. Ketika anak-anak tumbuh melalui fase di mana orangtua mereka terpisah, mereka terkena dampak dari perceraian orangtua.

Dampak perceraian orangtua terhadap anak yang paling sering ditimbulkan adalah pada perubahan sikap. Selain itu, ada beberapa sikap anak setelah orang tua bercerai, yang kadang tidak diperhatikan orangtuanya. Kehilangan merupakan sikap anak setelah orangtua bercerai yang paling jelas terlihat. Mereka akan merasa rendah, sedih, dan marah. Mereka tidak akan dapat fokus pada pendidikan atau masa-masa disayangi oleh orangtua mereka. Sangat penting bagi anak untuk segera keluar dari keadaan tersebut demi masa depan mereka kedepannya . Ini tentu menjadi tanggung jawab orangtua. Purwati D, (2010) menyatakan bahwa bunuh diri merupakan sikap untuk mencelakai diri, dikarenakan mereka tidak mendapatkan kasih sayang yang utuh dari orangtua mereka. mereka merasa bingung dikarenakan tidak ada yang bertanggung jawab atas masa depan mereka, mereka juga sangat bingung soal kebutuhan sandang dan pangan mereka setiap hari. Mereka berpikiran lebih baik mereka mengakhiri hidupnya dari pada tidak ada yang menjamin hidup mereka untuk kedepannya.

Berdasarkan hasil penelitian terlihat bahwa semua informan memiliki berbagai macam sikap setelah perceraian orangtua terjadi. Hal ini tampak dari hal - hal yang informan rasakan dan alami akibat perceraian dari orangtua. Berbagai sikap yang dapat peneliti temukan dari remaja yang orangtuanya bercerai dari masing-masing perasaan yang disampaikan oleh informan terkait dengan sikap ingin bunuh diri dan kehilangan akibat perceraian orangtua mereka. Adapun dari keempat informan dalam sikap mereka. Berdasarkan hasil wawancara mendalam secara langsung oleh peneliti ditemukan karakter yang sama yaitu merasa kehilangan dan perasaan ingin bunuh diri. 
Pembahasan sikap remaja dalam penelitian ini remaja setiap saat merasakan perasaan kehilangan karena tidak bisa bertemu dengan salah satu orang tua mereka yaitu ayah. Dalam wawancara mereka rata-rata mengatakan mereka merindukan kehadiran sosok seorang ayah dalam kehidupan mereka. bukan hanya merasa kehilangan karena orangtua bercerai. Salah satu dari informan juga mengatakan bahwa dia ingin bunuh diri disebabkan dia tidak bisa merasakan kasih sayang dari ayahnya. Saat orangtua berpisah, menyebabkan psikologis anak terganggu karena remaja harus menerima keadaan orangtuanya. Remaja juga menjadi korban dalam perceraian orangtua mereka. remaja tidak mendapat kasih sayang dari salah satu orangtuanya yaitu ayah. Karena ayah yang berperan penting dalam masa depan mereka.

Respon Remaja setelah orang tua bercerai dalam penelitian ini menunjukhan respon sedih disebabkan orangtua mereka bercerai. Rasa sedih pasti akan dirasakan oleh seorang anak, hal ini disebabkan oleh hilangnya sesuatu yang sudah dimiliki sejak ia belum menyadari apa apa. Dan anak pun cenderung untuk tidak menyadari bahwa kehilangan itu hanya berupa suatu yang sama hanya dalam bentuk yang berbeda. Seorang anak akan merasa nyaman ketika melihat kedua orangtua mereka harmonis seperti yang dialami teman-teman sebaya mereka. Perceraian orangtua mereka menorehkan luka batin yang menyakitkan buat mereka. dengan keadaan seperti ini mereka juga belajar menyesuaikan diri dengan keadaan yang mereka alami sekarang.. Sedih adalah reaksi yang paling mendalam bagi anak - anak ketika orang tuanya berpisah. Anak akan menjadi sangat bingung ketika hubungan orang tuanya tidak berjalan baik terutama jika mereka terus menerus menyakiti, entah secara fisik maupun vertikal (Purwati D, 2010).

\section{KESIMPULAN}

Pengetahuan remaja tentang perceraian orangtua yaitu remaja mengartikan perceraian adalah perpisahan antara kedua orangtua. remaja bersikap negatif tentang perceraian orangtua, yaitu adanya perasaan ingin bunuh diri dan perasaan kehilangan. Remaja memiliki respon afektif terhadap perceraian orangtua. Diharapkan hasil penelitian ini sebagai bahan pertimbangan remaja dapat terus bersikap positif dengan cara banyak mengikuti kegiatan ibadah sesuai agama masing-masing serta menjadi remaja yang berhasil kedepannnya agar orangtua bangga

\section{DAFTAR PUSTAKA}

Agustiani, H. (2006). Psikologi perkembangan, Pendekatan Ekologi kaitannya Konsep diri dan penyesuaian Diri pada Remaja. Bandung : Refika Aditama.

Asriandari E, (2015) Resiliensi Remaja Korban Perceraian Orangtua http:/ /journal.student.uny.ac.id/ojs/index.ph p/fipbk/article/download/265/243, Diakses 20 Januari 2017.

Brownlee, (2007). The effects of Divorce and associated Stressors on Children and Adolescent. Available on line : http ://grad.mnsu.edu/research/urc/journal/UR C2007journal/Brownlee.pdf.

Dariyo, Agoes. (2007). Psikologi Perkembangan Anak Tiga Tahun Pertama. Bandung; Refika Aditama

Keliat, B. A.,Helena, N.C.D.,\& Farida, P.(2007). Manajemen Keperawatan psikososial dan Kader Kesehatan Jiwa : CMHN (Intermedite Course). Jakarta : EGC.

Notoatmodjo S, (2010). Pendidikan dan perilaku kesehatan, Jakarta, Rineka Cipta

Purwati D, (2010), Gambaran Respon Berduka Pada Anak Remaja Dengan Orangtua Bercerai Dismp Negeri 1 Jatinangor Kabupaten Sumedang.

https://jurnal.unimus.ac.id/index.php/JKJ/a rticle/view/975, Diakses 20 Januari 2017.

Santrock, John W. (2012). Perkembangan Masa Hidup. Edisi. 13, Jakarta : Erlangga.

Suseno, A. (2005). Pemenuhan Kebutuhan Dasar Manusia Kehilangan, Kematian dan Proses Keperawatan. Jakarta. Agung Seto.

Wong, D, dkk. 2009. Buku Ajar Keperawatan Pediatrik. Volume 1. Penerbit. Buku Kedokteran: Jakarta, EGC. 